\title{
Medicinal plants used by the Kaiowá and Guarani indigenous populations in the Caarapó Reserve, Mato Grosso do Sul, Brazil
}

\author{
Norlene Regina Bueno', Rachel Oliveira Castilho ${ }^{1,6}$, Reginaldo Brito da Costa ${ }^{2}$, Arnildo Pott ${ }^{3}$, Vali J. Pott ${ }^{3}$, \\ Gessiel Newton Scheidt ${ }^{4}$ and Marcelo da Silva Batista ${ }^{5}$
}

Received: May 16, 2003; Accepted: July 13, 2004

\begin{abstract}
RESUMO-(Plantas medicinais usadas pelas populações indígenas Kaiowá e Guarani na Reserva de Caarapó, Mato Grosso do Sul, Brasil). Estudo etnobotânico realizado com a população indígena Kaiowá/Guarani na Reserva de Caarapó (Mato Grosso do Sul, Brasil) mostrou que 34 espécies vegetais, distribuídas em 22 famílias, têm propriedades medicinais e são utilizadas para o tratamento de diversas patologias. As informações obtidas foram: nome local em Português e em Guarani, indicações terapêuticas, preparação e a parte da planta utilizada. As principais plantas medicinais são usadas pela população indígena no tratamento de gripes e resfriados, dores abdominais, febres, reumatismos e para o tratamento de feridas.
\end{abstract}

Palavras-chave: população Kaiowá/Guarani, etnobotânica, plantas medicinais

ABSTRACT - (Medicinal plants used by the Kaiowá and Guarani indigenous populations in the Caarapó Reserve, Mato Grosso do Sul, Brazil). This ethnobotanical survey carried out with the Kaiowá and Guarani populations in the Caarapó Reserve (Mato Grosso do Sul, Brazil) showed that 34 plant species of 22 families with medicinal properties, are used for treating diverse pathologies. Local names in Portuguese and Guarani are provided, along with therapeutic indications, modes of preparation, and a description of the plant parts used. These folk-medicine plants have been mostly used for the treatment of influenza, abdominal pain, fever and rheumatism, and for wound healing.

Key words: Kaiowá and Guarani population, ethnobotany, medicinal plants

\section{Introduction}

Medicinal plants have been used in many cultures for thousand of years. Traditional plant-based medicine systems continue to play an essential role in health care. In fact, the World Health Organization (WHO) estimates that approximately $80 \%$ of the world's population rely mainly on traditional remedies for their health care (Gottlieb \& Kaplan 1993).

Few groups hold such a vast knowledge on the physical and chemical properties of plants as the South American natives (Lévi-Strauss 1985). Evidence of the influence of native knowledge on Brazilian medicine is demonstrated by the fact that a large number of indigenous drugs which therapeutic effects have been recognized by the Western medicine system, such as curare, coca, quinine and morphine, among others (Elizabetsky 1985).

Mato Grosso do Sul is the state that has the second largest indigenous population of the Brazil. The Kaiowá and Guarani populations, located in the south of the state of Mato Grosso do Sul, estimated about of 25,000 inhabitants (Brand 1998).

The confinement of Kaiowá and Guarani populations in the reserve dates back from 1915 . Several problems affect them nowadays, such as loss of their traditional homeland, confinement in reserves, deforestation of their territory, diseases and malnutrition (Vietta 1998; Brand 1998).

The main purposes of this study were to assess the traditional knowledge on medicinal plants used by the Kaiowá and Guarani, to gather information on their

\footnotetext{
${ }^{1}$ Universidade Católica Dom Bosco /UCDB, Curso de Farmácia, Av. Tamandaré, 6000, C. Postal 100, Jardim Seminário, CEP 79117-900, Campo Grande, MS, Brasil

2 Programa Kaiowá/Guarani, Universidade Católica Dom Bosco /UCDB

3 Centro Nacional de Pesquisa e Gado de Corte - CNPGC/EMBRAPA, BR 262 - Km 4, C. Postal 154, CEP 79002-970, Campo Grande, MS, Brasil

${ }^{4}$ Universidade Católica Dom Bosco /UCDB, Curso de Biologia, bolsista do CNPq

5 Centro Universitário da Grande Dourados/UNIGRAN, Curso de Biologia, Rua Balbina de Matos, 2.121, CEP 79824-900, Dourados, MS, Brasil

${ }^{6}$ Corresponding Author: Rua Ginás, 341, Jardim Jurá, CEP 79100-395, Campo Grande, MS, Brasil
} 
cultural and religious aspects, and to help preserve the knowledge of these populations.

\section{Material and methods}

Kaiowá and Guarani indigenous population and the Caarapó Reserve - The population interviewed for this ethnobotanical study was composed of Kaiowá and Guarani natives residing in the $36 \mathrm{~km}^{2}$ Caarapó Reserve located in the south of the state of Mato Grosso do Sul, between latitudes $22^{\circ} 34^{\prime} \mathrm{S}$ and $22^{\circ} 38^{\prime} \mathrm{S}$ and longitudes $54^{\circ} 55^{\prime} \mathrm{W}$ and $55^{\circ} 1^{\prime} \mathrm{W}$ (Figure 1). Mean altitude is $500 \mathrm{~m}$ and annual mean temperature is $20-22^{\circ} \mathrm{C}$. It's possible to identify three different forestal formations: semi-deciduous forest, Open Arboreous Savana and and Dense Arboreous Savana. Soils are mainly humic rhodic ferrasols, followed by acrisols and rhodic acrisols. In the riverine portions, slight humic gleysols prevail Secretaria de Planejamento e Coordenação Geral (SEPLAN/MS 1989).

This population is estimated at 25,000 individuals distributed in eight reserves in Mato Grosso do Sul, comprising 14 villages. The Guarani are conventionally classified into three subgroups: Ñandeva/Chiripá, Mbyá and Kaiowá. Ñandeva/Chiripá familial groups - the only ones self-described as Guarani - are present in all the reserves where the Kaiowá predominate. (The term Kaiowá and Guarani is used for referring to aspects that are common to both subgroups) (Brand 1998). The Kaiowá and Guarani living in the Caarapó Reserve speak Guarani (Filho 1998).

Ethnobotanical informations - This survey was performed from 1999 to 2001. Information was collected by interviewing on location ten elderly native members of the communities, most of them women, whose knowledge was widely respected.

The interviews were accomplished through conversations in which those being interviewed provided answers to topics of a previously structured questionnaire. The information collected included data such as local names in Portuguese and Guarani, ailments and diseases treated, therapeutic effects, plant parts used, modes of preparation and place of collection Martin (1995). After that, the results of the survey, citations number and $\%$ citations were reported in a Table 1.

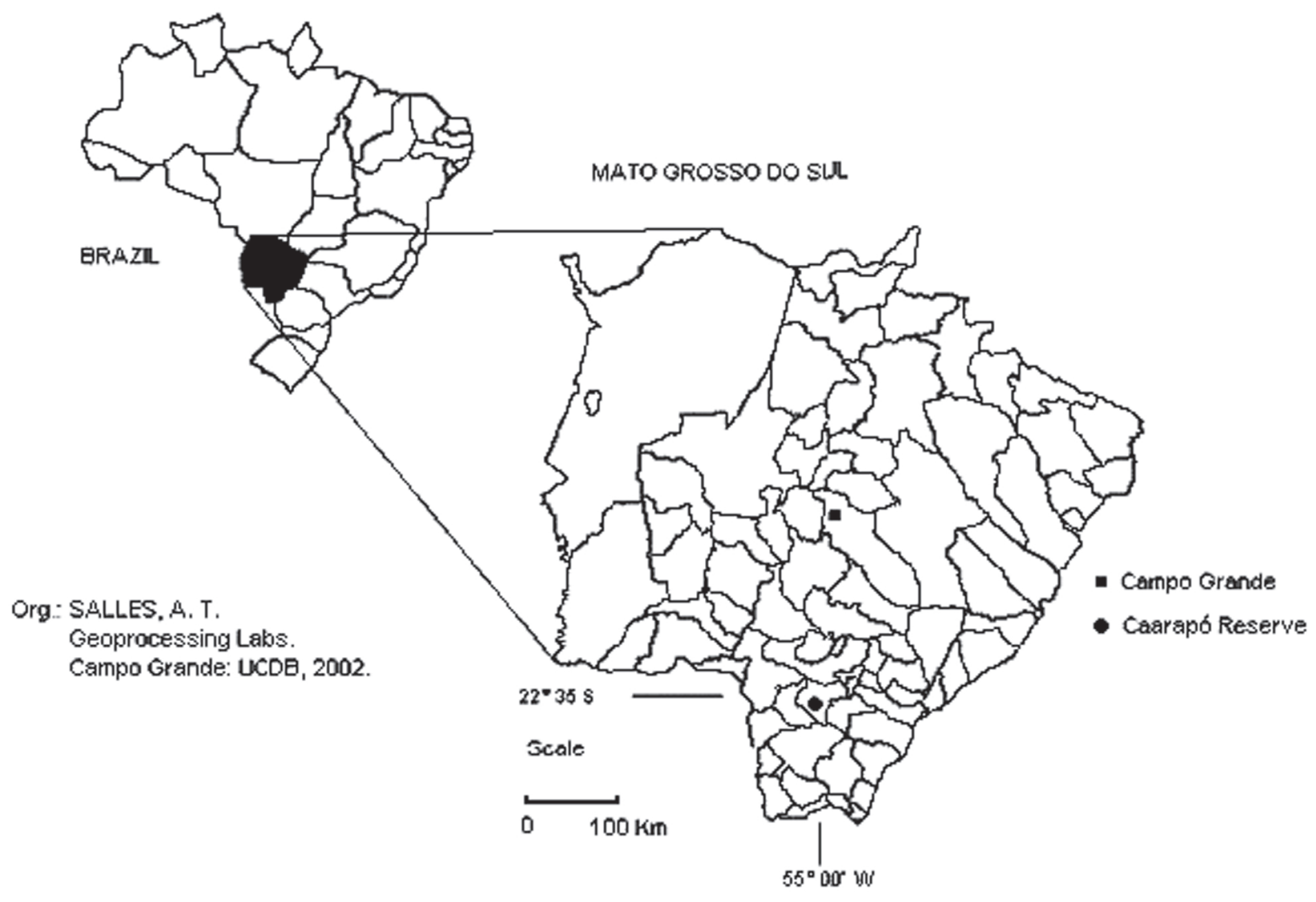

Figure 1. Location of Kaiowá and Guarani populations in the Caarapó Reserve, Mato Grosso do Sul state. 
Table 1. Medicinal plants used by the Kaiowá and Guarani indigenous populations in the Caarapó Reserve, Mato Grosso do Sul, Brazil.

\begin{tabular}{|c|c|c|c|c|c|c|}
\hline $\begin{array}{c}\text { Families, botanical names and } \\
\text { voucher specimens }\end{array}$ & $\begin{array}{l}\text { Local } \\
\text { portuguese names }\end{array}$ & $\begin{array}{l}\text { Guarani } \\
\text { names }\end{array}$ & $\begin{array}{l}\text { Conditions treated } \\
\text { and other uses }\end{array}$ & Plant parts & $\begin{array}{l}\text { Modes of } \\
\text { preparation }\end{array}$ & $\begin{array}{r}\text { Citations (n) } \\
\text { and } \% \text { citations }\end{array}$ \\
\hline \multicolumn{7}{|l|}{ ANACARDIACEAE } \\
\hline $\begin{array}{l}\text { Myracrodruon urundreuva } \\
\text { Fr. All. } 4356\end{array}$ & aroeira & - & toothache, styes & bark and leaves & - & $4-40 \%$ \\
\hline \multicolumn{7}{|l|}{ ANNONACEAE } \\
\hline Annona coriacea Mart. 4357 & araticum & aratiku & earaches & $\begin{array}{l}\text { leaves, bark } \\
\text { and roots }\end{array}$ & infusion & $1-10 \%$ \\
\hline \multicolumn{7}{|l|}{ ARALIACEAE } \\
\hline $\begin{array}{l}\text { Didymopanax morototoni (Aubl.) } \\
\text { B. Maguire, Steyerm Dcne. et } \\
\text { Planch } 4354\end{array}$ & mandiocão & - & irregular menses $\quad r$ & roots, bark, leaves & infusion & $1-10 \%$ \\
\hline \multicolumn{7}{|l|}{ ARISTOLOCHIACEAE } \\
\hline $\begin{array}{l}\text { Aristolochia brasiliensis Autn. } \\
\text { M. et Zucc. } 4342\end{array}$ & $\begin{array}{l}\text { cipó- } \\
\text { milombre }\end{array}$ & $\begin{array}{l}\text { ysypo } \\
\text { milombre }\end{array}$ & abdominal pain & whole plant & infusion & $2-20 \%$ \\
\hline \multicolumn{7}{|l|}{ BIGNONIACEAE } \\
\hline $\begin{array}{l}\text { Tabebuia avellanedae Lor. } \\
\text { ex Griseb. } 4367\end{array}$ & ipê-roxo & tajy & tuberculosis, fever & bark & infusion & $2-20 \%$ \\
\hline \multicolumn{7}{|l|}{ BIXACEAE } \\
\hline $\begin{array}{l}\text { Bixa orellana L. } 4365 \\
\text { BOMBACACEAE }\end{array}$ & urucum & uruku & tooth extraction & roots & infusion & $1-10 \%$ \\
\hline $\begin{array}{l}\text { Erioteca candolleana (K. Schum.) } \\
\quad \text { A.Rob. } 4343\end{array}$ & catuaba & yvá porũ & $\begin{array}{c}\text { rheumatism, } \\
\text { nerves }\end{array}$ & roots & infusion & $2-20 \%$ \\
\hline \multicolumn{7}{|l|}{ CELASTRACEAE } \\
\hline $\begin{array}{l}\text { Maytenus ilicifolia Mart.ex } \\
\quad \text { Reiss } 4344\end{array}$ & cancorosa & - & $\begin{array}{l}\text { abdominal pain, } \\
\text { wound healing }\end{array}$ & whole plant & infusion & $2-20 \%$ \\
\hline \multicolumn{7}{|l|}{ COMPOSITAE } \\
\hline $\begin{array}{l}\text { Achyrocline satureioides (Lam.) } \\
\text { DC. } 4345\end{array}$ & macela & macela & $\begin{array}{l}\text { digestive, } \\
\text { rheumatism }\end{array}$ & leaves & infusion & $3-30 \%$ \\
\hline $\begin{array}{l}\text { Gochnatia polymorpha Herb. } \\
\text { Berol ex DC. ssp. polymorpha } 43\end{array}$ & $4366^{\text {candeia }}$ & tatarẽm & sore throat & bark & infusion & $1-10 \%$ \\
\hline Solidago microglossa DC. 4349 & $\begin{array}{l}\text { arnica-do- } \\
\text { campo }\end{array}$ & taji pita’ $\widetilde{i}$ & $\begin{array}{c}\text { kidney } \\
\text { disturbances }\end{array}$ & roots & infusion & $1-10 \%$ \\
\hline $\begin{array}{l}\text { Baccharis trimera DC. } 4337 \\
\text { CUCURBITACEAE }\end{array}$ & carqueja & kacare ka'a & colics, anemia & fruit & infusion & $2-20 \%$ \\
\hline $\begin{array}{l}\text { Citrullus vulgaris Schrad. } 4341 \\
\text { LEGUMINOSAE }\end{array}$ & melancia & - & colics, vomiting & seed & infusion & $2-20 \%$ \\
\hline $\begin{array}{l}\text { Anadenanthera falcata (Benth.) } \\
\text { Speg. } 4362\end{array}$ & angico & - & $\begin{array}{l}\text { conjunctivitis, } \\
\text { scabies }\end{array}$ & bark & infusion & $3-30 \%$ \\
\hline Copaifera langsdorffii Desf. 4360 & pau-de-óleo & kupa'y & $\begin{array}{l}\text { influenza, } \\
\text { bronchitis }\end{array}$ & bark & infusion & $1-10 \%$ \\
\hline Dimorphandra mollis Benth. 4352 & 2 barbatimão & loritopuisã & spine pains & bark & infusion & $2-20 \%$ \\
\hline Hymenaea courbaril L. 4359 & jatobá & Jatayva & $\begin{array}{l}\text { digestive } \\
\text { disturbances, } \\
\text { influenza }\end{array}$ & bark & infusion & $6-60 \%$ \\
\hline Peltophorum dubium (Spreng.) 4361 & 1 canafístula & yvira pitã & wound healing & bark & - & $1-10 \%$ \\
\hline $\begin{array}{l}\text { Pterodon emarginatus Vog. } 4370 \\
\text { LYTHRACEAE }\end{array}$ & sucupira & yviraperó & headaches, fever & - & - & $2-20 \%$ \\
\hline $\begin{array}{l}\text { Lafoensia pacari A. St.-Hil.4353 } \\
\text { MELIACEAE }\end{array}$ & pacuri & - & pneumonia & fruit & - & $1-10 \%$ \\
\hline $\begin{array}{l}\text { Cabralea canjerana (Vell.) } \\
\quad \text { Mart. } 4351\end{array}$ & cajarana & kacharana & skin conditions & bark & - & $1-10 \%$ \\
\hline Cedrela fissilis Vell. 4364 & cedro & yary & influenza, headaches & bark & infusion & $2-20 \%$ \\
\hline \multicolumn{7}{|l|}{ MORACEAE } \\
\hline Ficus inspida Willd. 4363 & figueira & - & $\begin{array}{l}\text { wound healing, } \\
\text { rheumatism }\end{array}$ & bark, leaves & - & $5-50 \%$ \\
\hline Maclura tinctoria (L.) & moreira & yvira piriri & toothaches & bark & infusion & $1-10 \%$ \\
\hline
\end{tabular}


Table 1 (continuation)

\begin{tabular}{|c|c|c|c|c|c|c|}
\hline $\begin{array}{c}\text { Families, botanical names and } \\
\text { voucher specimens }\end{array}$ & $\begin{array}{l}\text { Local } \\
\text { portuguese names }\end{array}$ & $\begin{array}{c}\text { Guarani } \\
\text { names }\end{array}$ & $\begin{array}{l}\text { Conditions treated } \\
\text { and other uses }\end{array}$ & Plant parts & $\begin{array}{l}\text { Modes of } \\
\text { preparation }\end{array}$ & $\begin{array}{r}\text { Citations (n) } \\
\text { and } \% \text { citations }\end{array}$ \\
\hline \multicolumn{7}{|l|}{ D. Don ex Steud 4346} \\
\hline \multicolumn{7}{|l|}{ MUSACEAE } \\
\hline Musa paradisiaca L. 4336 & banana-nanica & $\begin{array}{l}\text { pacova } \\
\text { karape }\end{array}$ & snake bites & stem & juice & $1-10 \%$ \\
\hline \multicolumn{7}{|l|}{ MYRSINACEAE } \\
\hline $\begin{array}{l}\text { Rapanea ferruginea (Ruiz et Pav.) } \\
\text { Mez } 4371\end{array}$ & pororoca & yvirare & mumps & leaves & infusion & $1-10 \%$ \\
\hline \multicolumn{7}{|l|}{ MYRTACEAE } \\
\hline Eugenia uniflora L. 4348 & pitanga-mirim & pitanga'i & $\begin{array}{l}\text { stomach pains, } \\
\text { diarrhea }\end{array}$ & leaves, bark & - & $1-10 \%$ \\
\hline $\begin{array}{l}\text { Myrcianthes pungens (O. Berg) } \\
\text { D. Legrand } 4350\end{array}$ & guavira-guaçu & guavira & abdominal pains & bark & - & $1-10 \%$ \\
\hline Psidium guajava L. 4358 & goiaba & araça & diarrhea, vomiting & leaves & infusion & $1-10 \%$ \\
\hline PHYTOLACACEAE & & & & & & \\
\hline Petiveria alliacea L. 4338 & guiné & pikatî & snake bites, cough & leaves, roots & - & $3-30 \%$ \\
\hline \multicolumn{7}{|l|}{ PIPERACEAE } \\
\hline Pothomorphe umbellata Miq. 4339 & 9 pariparoba & parioparova & $\begin{array}{c}\text { influenza, } \\
\text { headaches,fever }\end{array}$ & leaves & infusion & $2-20 \%$ \\
\hline \multicolumn{7}{|l|}{ RUTACEAE } \\
\hline $\begin{array}{l}\text { Helietta apiculata } \text { Benth. } 4368 \\
\text { URTICACEAE }\end{array}$ & canela-de-veado & yvira ovi & wound healing & bark & infusion & $1-10 \%$ \\
\hline Urtica urens L. 4340 & urtiga-do-campo & - & $\begin{array}{l}\text { against } \\
\text { Dermatobia hominis }\end{array}$ & roots & - & $1-10 \%$ \\
\hline $\begin{array}{l}\text { VERBENACEAE } \\
\text { Stachytarpheta cayennensis } \\
\text { (Rich.) Vahl } 4355\end{array}$ & gervão & jervon & $\begin{array}{l}\text { stomach pains; } \\
\text { spine pains }\end{array}$ & $\begin{array}{l}\text { bark, roots, } \\
\text { leaves }\end{array}$ & infusion & $1-10 \%$ \\
\hline
\end{tabular}

Taxonomic identification - After the interviews, all the plants mentioned were recognized in the field by the interviewed, and then collected and taxonomically identified by the botanicals Dr. Arnildo Pott and Dra. Vali J. Pott (Centro Nacional de Pesquisa e Gado de Corte - CNPGC/EMBRAPA). Voucher specimens are kept for reference in the HMS Herbarium of Embrapa (Empresa Brasileira de Pesquisas Agropecuárias) in the city of Campo Grande.

\section{Results and discussion}

The plants used as medicinal by Kaiowá and Guarani populations are reported in Table 1, arranged in alphabetical order of their botanical name, followed by voucher specimen number, the vernacular (local Portuguese name), Guarani name, conditions treated and other uses, the parts used as a medicine, the preparations in which drugs are employed, citations number and $\%$ citations.

The Kaiowá and Guarani populations use at least 34 different plants of 22 families to treat many kinds of pathologies. The plant families with the greatest number of citations were: Leguminosae (6), Compositae (4), Myrtaceae (3), Moraceae (2) and Meliaceae (2) (Figure 2). These five families comprised $50 \%$ of all the genera cited. The Kaiowá and Guarani get their medicinal plants from the woods, fields, swamps, and even from home yards. The bark is the most used part of the plant, being prepared mainly as an infusion (23 plants) (Figure 3).

The folk-medicine plants mentioned are used mostly for the treatment of influenza (3), abdominal pain (4), fever (2) and rheumatism (3), and for wound healing (4). Most of the species have a single therapeutic indication, as example pathologies of the respiratory tract, such as cough (1), pneumonia (1), bronchitis (1), sore throat (1). Urtica urens and Anandenanthera falcata are used for the treatment against Dermathobia hominis and scabies, respectively. U. urens is used, not only in human, but also in animal treatment.

The following vegetables are used for more than one pathology: Potomorphe umbellata, related with 


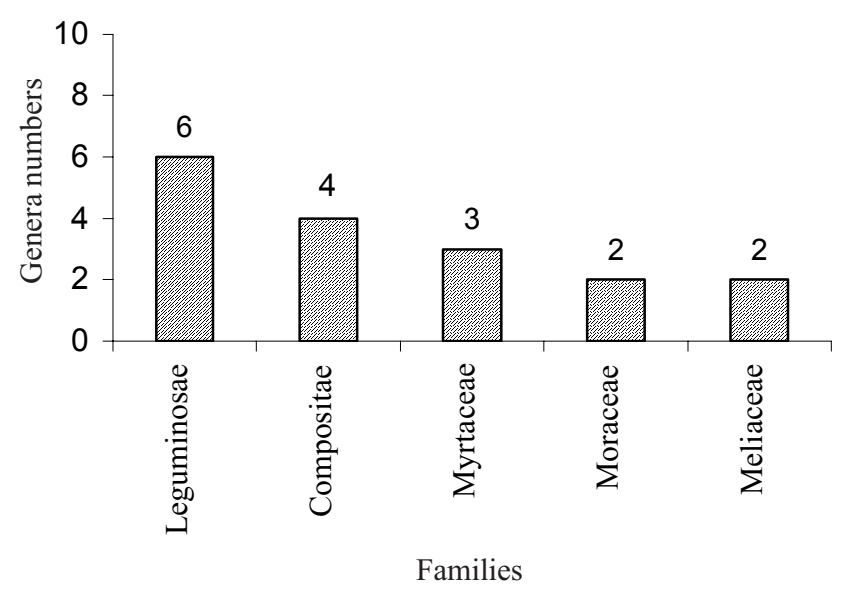

Figure 2. The main families used by the Kaiowá and Guarani population in Caarapó Reserve, Mato Grosso do Sul, Brazil.

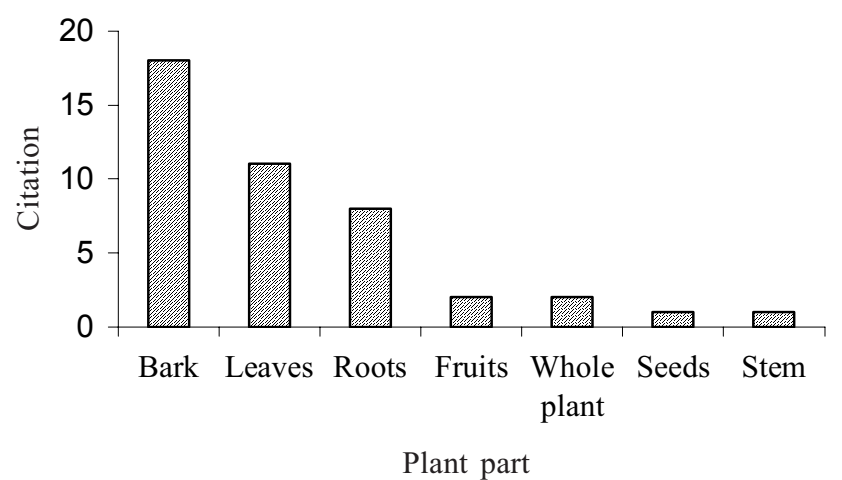

Figure 3. The part of the plant used by Kaiowá and Guarani population in Caarapó Reserve, Mato Grosso do Sul, Brazil.

influenza, headache, feber; Erioteca candolleana, which is used for rheumatism and nerves; Hymenaea courbaril, used for digestive disturbances and influenza; Citrullus vulgaris, for colics and vomiting.

Most of the plants mentioned in the interviews with native members of the Kaiowá and Guarani populations are already popularly known and used as phytomedicine. Examples include: Bixa orellana, which is used as dyeing (for indigenous body painting) and as seasoning; Achyrocline satureioides, used for digestive problems such as intestinal colics, nausea, flatulence, diarrhea, and as an antimicrobial and antiviral; Maytenus ilicifolia, used for the treatment of digestive ulcers, for wound healing and as an analgesic; Baccharis trimera, for digestive problems, hypoglycemia and verminoses; Eugenia uniflora, for digestive problems; Ficus insipida, which has laxative and emollient action; Psidium guajava, used for diarrhea and wound healing; Stachytarpheta cayennensis, with hypoglycemic and fungicide action, and used for treating diarrhea; Tabebuia avellanedae, with antiseptic action and used for the treatment of cancer; Urtica urens, used as an anti-inflammatory and expectorant, etc. (Simões et al. 2002, Rizzini and Mors 1995, Baelmans 2000).

Among the indications given by the indigenous population regarding known plants, new therapeutic uses have been recorded. The following are worth mentioning: Tabebuia avellanedae is used for the treatment of tuberculosis; Bixa orellana, in the extraction of teeth; Petiveria alliacea, for snake bites and coughs.

Comparisons with other ethnobotanical surveys carried out in Caarapó Reserve are not proposed because they are not reported in the previous phytotherapy works consulted.

The present study shows that Kaiowá and Guarani populations has an important knowledge about potential therapeutic of several plant species in the Caarapó Reserve. Ethnobotanical surveys are an important contribution to help transmit traditional knowledge to future native generations, to foster the planting of species now under threat of extinction and to suggest "new" species that may deserve further pharmacological or phytochemical studies.

\section{Acknowledgements}

We are grateful to Dr. Angela Elizabeth Lapa Coêlho, to MSc. Ayr Trevisanelli Salles, to Dr. Arnildo Pott and Dra. Vali Joana Pott and to all the members of the indigenous communities who provided us with information on medicinal plants.

\section{References}

Baelmans, R.; Deharo, E.; Bourdy, G.; Munõz, V.; Queneva, C.; Sauvain, M. \& Ginsburg, H.J. 2000. A search for natural bioacte compounds in Bolivia through a multidiciplinar approach. Part IV. Is a new haem polymerization inhibition test pertinent for the detection of antimalarial natural products? Journal of Ethnopharmacology 73(1-2): 271.

Brand A. 1998. "Quando chegou esses que são nossos contrários" - A ocupação espacial e o processo de confinamento dos Kaiowá/Guarani no Mato Grosso do Sul. Multitemas 12: 21-51.

Elisabetsky, E. 1986. Etnofarmacologia de algumas tribos brasileiras. Pp.135-148. In: D. Ribeiro (ed.). Suma Etnológica Brasileira - 1. Etnobiologia. Petrópolis, Vozes, Finep.

Filho, A.J. 1998. Bilingüismo e Educação Bilíngüe Kaiowá/ Guarani na Reserva Indígena de Caarapó/MS Multitemas 12: 176-193. 
Gottlieb, O.R. \& Kaplan, M.A.C. 1993. Das plantas medicinais aos fármacos naturais. Ciência Hoje 89: 51-54.

Lévi-Strauss, C. 1985. O uso das plantas silvestres da América do Sul tropical. Pp.29-56. In: D. Ribeiro (ed.). Suma Etnológica Brasileira - 1. Etnobiologia. Petrópolis, Vozes, Finep.

Martin, G.J. 1995. Ethnobotany — a methods manual. Londres, Chapman \& Hall.

Rizzini, C.T. \& Mors, W. 1995. Botânica Econômica Brasileira. Rio de Janeiro, Âmbito Cultural.
Simões, C.M.O.; Schenkel, E.P.; Gosmann, G.; Mello, J.C.P.; Mentz, L.A. \& Petrovick, P.R. 2002. Farmacognosia: da planta ao medicamento. Porto Alegre/Florianópolis, Ed. UFRGS/Ed. da UFSC.

Secretaria de Planejamento e Coordenação Geral (SEPLAN/MS). 1989. Macrozoneamento geoambiental do Estado de Mato Grosso do Sul. Campo Grande, FIPLAN/MS.

Vietta, K. \& Brand, A. 1998. Programa Kaiowá/Guarani: a pesquisa científica a serviço da comunidade Multitemas 12: 9-20.

Versão eletrônica do artigo em www.scielo.br/abb 